\title{
Research on the Teaching Reform of Advanced Financial Accounting -Based on Flipped Classroom Teaching Model
}

\author{
Yinling Liu ${ }^{1, a^{*}}$ and Yang $\mathrm{Gao}^{2, \mathrm{~b}}$ \\ ${ }^{1}$ School of Management, Yulin University, China,719000 \\ ${ }^{2}$ Career Technical College Yulin, China,719000 \\ a263050607@qq.com, ${ }^{\mathrm{b}} 3068928155 @ q q . c o m$
}

Keywords: Advanced financial accounting; Case guidance; Flipped classroom; Online classroom.

\begin{abstract}
Advanced Financial Accounting is a supplement, extension and development to Intermediate Financial Accounting,. It is mainly to solve a series of special operations produced with the objective economic environment changes and emerging business. Its research object is complicated, involving the knowledge points across each other. Therefore, we can not regard knowledge points as teaching objectives, but should focus more on the training of flexible use of knowledge. This study is based on the analysis of the situation of "Advanced Financial Accounting ", combined with advanced concepts and methods of teaching, and case teaching as a guide, fully mobilize the enthusiasm of students to participate in classroom training, and improve students' problem-solving skills, as well as build flipped classroom teaching mode.
\end{abstract}

\section{Introduction}

By breaking the traditional basic assumptions of accounting, "Advanced Financial Accounting" is closely linked to the development of enterprises and market economy. It involves not only a wide range of disciplines, but also a solid theoretical foundation and comprehensive ability to use knowledge. Therefore, the course is difficult to learn, and even some students give up learning[1].

\section{Teaching status of Advanced Financial Accounting}

There are four characteristics of "Advanced Financial Accounting" such as "advanced, profound, difficult, special" , which makes it is different from Intermediate Financial Accounting. Due to the lack of teaching hours, limited ability to accept students, improper teaching methods and so on, there are some problems in the teaching of Advanced Financial Accounting.

Teaching method is not proper. At present, " Advanced Financial Accounting" still adopts the traditional teacher-centered mode[2]. Although teacher has asked students to preview teaching contents, but few students can do this indeed. Moreover, the content of Advanced Financial Accounting course is very difficult to understand, and even if students preview it, they can not play a substantive role. Therefore, teacher's indoctrination is still the main form, questioning is also a mere formality. The biggest drawback of this model is that it can not mobilize the enthusiasm of students, can not let students better participate in the classroom, can not meet the requirements of application-oriented talents training, and also can not achieve the purpose of applying knowledge. And since the content of the course is more profound, students simply listen to the teaching that is difficult to understand, and even listening can be hypnotic.

Teaching tools need to be improved. Although "Advanced Financial Accounting" uses blackboard writing and multimedia teaching method, but "micro class" 、"Mu class" and other modern new teaching methods are few[2]. Moreover, "Advanced Financial Accounting" course needs to integrate many fragmentary knowledge points in Intermediate Financial Accounting to solve the actual business, which requires a large amount of knowledge review. If the review of the Intermediate Financial Accounting knowledge is carried out in the classroom, it will lead to the problem that the teaching period is not enough. Current teaching methods have limited course teaching in a narrow space such as "classroom", 
unable to integrate the whole process, and learning is basically terminated when leaving the classroom. Those teaching methods can not attract the students' eyes, but also can not stimulate students' interest in learning. In current society which is filled with high technology and huge amount of information, only by constantly updating the means of knowledge dissemination and acceptance, we can keep pace with the pace of social development, and adapt to the needs of talents in the era of knowledge economy.

Performance evaluation standards need to be reformed. At present, "Advanced Financial Accounting" uses usual performance plus final exam results to evaluate. Usual results include attendance, classroom performance and homework three parts. Due to limited classroom teaching period, teachers can not recognize all students, question one by one but through general impression to complete the scoring. Homework is usually copied from each other, the whole class is almost a version, can not reflect the actual level of students. Final exam is to test the knowledge points in the form of the test paper. Students tend to be cramming for the exam review. This model completely violates the talent training goal of Application-oriented Universities.

\section{The planning of flipped classroom teaching mode}

Flipped classroom refers to change the teachers' explaining mode instead of learning by students themselves, letting the students to focus on facing problems in the curriculum content in the limited classroom time, so as to enhance the students' understanding, faster to learn knowledge[3].

Teaching ideas of flipped classroom. First of all, before each chapter of teaching, teachers will give students case and questions. Students can have a preliminary understanding of the actual task of this chapter through reading and thinking. That is to say, let the students with the task to complete successive learning with questions, to understand and grasp the focus of teaching. In order to get rid of the past "cramming" single "injection" teaching methods, in order to mobilize the enthusiasm of the students. In the arrangement of questions, teachers will prompt students to think from what point of view, what knowledge or reference points.

Secondly, all students are divided into groups to discuss before class. The teacher will appoint two groups to publish the results of the group discussion in the classroom, explain the reasons or reasons, and form a written report. In the written report, the basic theory underlying the results of the discussion will be clearly explained, as well as the views of each group member in this discussion. At the same time, the written report will also be the key element in the assessment of the performance of group work. In this way, it can not only avoid a version of the whole class homework, but also improve the students' ability to apply the learned knowledge. Other groups can according to different results or opinions are added. This discussion can fully mobilize the enthusiasm of student, improve students' ability to find out problems, analyze and solve problems, which will let students fully participate in classroom teaching, become the "protagonist" in the classroom.

Finally, the teacher provides comments. On one hand, teachers can affirmed or praise the students' performance in the discussion of questions through analyzing ability, decision-making ability, expression ability and self defense capability; on the other hand, the teacher should emphasize students in question discussion ignored or wrong, and motivate them to analyze the causes, and then leads to teaching the emphasis and difficulty of this chapter.

In the past teaching process, the teaching order is to explain the accounting standards first, and then exercise. In flipped classroom teaching mode, the teacher guides students to infer the accounting standards on the basis of the intermediate financial accounting theory that has been mastered, and then to verify whether the speculation is correct or not. Obviously, this model is helpful for students to understand and master the teaching content, improve their ability to apply knowledge and analyze problems.

The auxiliary means of flipped classroom teaching. Applying "rain classroom" software to set up "Advanced Financial Accounting" online class. The teacher can upload all kinds of teaching materials, courseware and exercises to the online class through the client. Students can join the classroom through the WeChat platform to learn course content anytime, anywhere, and communicate with teachers to explore. The concrete implementation steps are as follows: 
First of all: before each classroom teaching, the teacher upload case data to the online classroom, and incidental thinking or small test questions, so that students to analyze cases ahead of time."Rain class" software has statistical function, teachers in the background can see which students read the case, which students did not read, which students made the test questions wrong, which students to test questions correctly. This method can greatly improve the teacher's understanding of students, can also "forced" students to learn to a large extent and put an end to the students "ride the car" situation.

Secondly, in classroom teaching, teachers' teaching courseware can be uploaded to the online classroom, using voice on page courseware to explain. For the content that is not understood in class, students can continue to read the courseware after class to review. At the same time, students can also click on the "don't understand" button for the courseware that is not understood. This method is helpful for teachers to grasp the learning situation of students in time. Teachers can also push classroom practice, let the students do the exercises in the mobile phone, according to the exercises on the wrong to understand the students' mastery of knowledge, reduce the "fish in troubled waters."

Finally, after the completion of the task of classroom teaching, students can give feedbacks of teaching effect and teachers can know the teaching effect in the first time in order to adjust the way to explain or improper place.

Application examples of flipped classroom. This study takes "foreign currency statement translation accounting" as an example to illustrate the application of flipped classroom teaching mode in Advanced Financial Accounting teaching.

First, arrange cases before class, guide students to discover and think about problems. Before class, the teacher uploaded the case data related to the foreign currency statements in China Railway 2015 annual report to the rain class.

Table 1 shareholders' equity in the balance sheet [thousand yuan]

\begin{tabular}{|l|l|l|}
\hline Project & Year End Balance & Beginning Balance \\
\hline Capital stock & 21299900 & 21299900 \\
\hline Capital reserve & 41386022 & 41381550 \\
\hline Surplus public accumulation & 1997078 & 1587776 \\
\hline Undistributed profit & 10925341 & 8349214 \\
\hline Converted difference in Foreign Currency Statements & $(10450)$ & $(6538)$ \\
\hline Total Equity & 75597891 & 72611902 \\
\hline
\end{tabular}

After Table 1, supplementary guidance of thinking: the interests of the owner of part of the table in a number of "foreign currency translation differences", this is not seen in the intermediate financial accounting, the content of accounting identities "assets = Liabilities + equity" can be established ? If the identity still holds, then why does it happen?

Table 2 converted exchange rates of main reports of overseas operating entities

\begin{tabular}{|l|l|l|l|l|}
\hline Project Location & $\begin{array}{l}\text { Bookkeeping } \\
\text { Base Currency }\end{array}$ & Report Item & $\begin{array}{l}\text { Converted } \\
\text { Exchange Rate }\end{array}$ & $\begin{array}{l}\text { Types of converted exchange } \\
\text { rates }\end{array}$ \\
\hline \multirow{3}{*}{ Papua New Guinea } & Keener & asset & 0.3967 & Final spot rate \\
\cline { 3 - 5 } & & Liability & 0.3967 & Final spot rate \\
\cline { 3 - 5 } & Owners' equity & 0.3753 & $\begin{array}{l}\text { istorical exchange rate at the } \\
\text { time of occurrence }\end{array}$ \\
\cline { 3 - 5 } & & Profit and loss & 0.3648 & Current average exchange rate \\
\hline
\end{tabular}

After Table 2, additional guided thinking questions are as follows: What are the implications of the various exchange rates in the table? Why do the asset and liability projects choose the spot exchange rate at the end of the term, while the owner's equity class chooses the historical exchange rate at the time of the event? Where is the reason? hint: thinking from the characteristics of enterprise accounting 
information reflected in the balance sheet. Why does the profit and loss item choose the current average exchange rate to be translated, and does it have a translation difference? If yes, what is the relationship with the conversion balance in the balance sheet? hint: starting from the balance sheet and the profit relation between tables to think about the problem.

Next: group discussion, participate in the classroom. The whole class is divided into four groups, the two group is responsible for answering case thinking, and the other two groups are responsible for comment and make different views. $t$ is also stipulated that the students who speak each time can not be the same, so as to mobilize the enthusiasm of each student to participate in the class. In the process of students answering questions, on one hand, teachers should be recorded on different answers to review and verification process subsequently required; on the other hand, teachers should play the guiding role of the students answered: if students answer to the correct answer, the teacher can give appropriate, if the student is wrong, the teacher can be added at any time to let the students themselves to overthrow their erroneous points of view. For example, if the student's answer is that the balance sheet reflects the financial statements of the assets, liabilities and owner's equity of the enterprise. Teachers can further add: balance sheet reflects when the enterprise's financial situation? In order to guide students to analyze the balance sheet reflects the financial status of the enterprise on the balance sheet date, rather than the other day of the financial situation. Therefore, when converting the balance sheet of foreign currency, the asset and liability items can only be adjusted at the spot exchange rate of the balance sheet date, that is, the spot exchange rate at the end of the term. This teaching method can not only make students have a stronger impression of existing knowledge, but also let the students grasp the methods of using existing knowledge to analyze the new problems, so as to enhance the self-confidence of students, and mobilize the enthusiasm of students in the classroom, so that students become the center of classroom teaching. This link will take half of the total class time, give students more time and opportunity to participate in the classroom, so that they gradually learn to find problems, analyze problems and solve problems.

Finally: teacher comments, common inferences, and guidelines are compared. After the discussion session, the teacher can take the students together to sum up the main content of "foreign currency statements translation accounting". In the translation of foreign currency statements, there is no big difference between the basic theory and the intermediate financial accounting. From the final report, only increased the exchange rate and foreign currency statements conversion balance of two items. Therefore, as long as students master the meaning of various exchange rates and the characteristics of each item of the financial statements, the calculation of the choice of exchange rate and the calculation of the converted balance can be mastered. The difficulty of this chapter lies in the conversion of owner's equity items. The teacher can start with the content of the owner's equity project that the students have mastered, and lead the students to recall the characteristics and calculation methods of each content.

For example, the converted exchange rate of the paid in capital should be analyzed from the source of the paid in capital and the law of development and change. Real capital occurs in the past, not now, and the amount will not change, unless the investor increases the investment, withdrawals or surplus reserves into the capital. Therefore, the content reflects the historical investment accepted by the enterprise, so the choice of historical exchange rate conversion is reasonable.

Surplus reserve comes from net profit of enterprise, so its translation rate should choose the same exchange rate as net profit. At the same time, the final balance of the surplus reserve project is generally based on the initial balance, plus the increase in the current part of the extraction, involving both the beginning of the exchange rate, but also related to the end of the exchange rate. Therefore, the conversion of surplus reserve should be converted into the initial foreign currency amount and the amount of foreign currency in the current period. The amount of foreign currency exchange at the beginning of the period can be obtained from the final data of the previous report. The amount of foreign currency added in this period is derived from the distribution of profits, and the same exchange rate should be chosen to convert the net profit to the same period.

After the teacher led the students to speculate the converted exchange rate, and then compared with the accounting standards, not only for students to accept new knowledge faster, but also help students firmly grasp the knowledge. 
Examination methods of flipped classroom. Flipped classroom teaching model pays more attention to the pre - class preparation and the group discussion. First of all, teachers can use the "rain" in the classroom "sign", "test" to "monitor" the students before class, in class and after class learning, can fully understand the students' learning attitude and learning effect, give students objective scoring. Secondly, teachers can fully understand the students' perspectives and methods of the analysis problems through the group discussion in the class and the discussion reports of each group, and give the students an objective and fair evaluation. Finally, there should be an increasing in the ratio of the application of the title in the final examination paper to assess students' practical ability to use knowledge.

\section{Conclusion}

To sum up, the teaching of Advanced Financial Accounting should aim at the cultivation of applied talents, focusing on training students' ability to discover problems, analyze problems and solve problems. In the process of teaching, teachers should take the students to participate in teaching "instead of," cramming "teaching mode; starting from the actual business case analysis, to enable students to gradually understand the new teaching content, and apply the knowledge to enhance students' ability to speculate that the comprehensive use of knowledge; make full use of various teaching software service platform and advanced teaching ideas and methods to create a good teaching atmosphere, enhance communication and interaction between teachers and students, improve teaching efficiency and learning efficiency, the traditional" classroom time "unlimited extension.

\section{References}

[1] P.P. Cang and Q.J. Wang: Communication of Finance and Accounting,Vol.23 (2014 )No 22, P.43.(In Chinese)

[2] C.L. Tan: Accounting of Township Enterprises in China,Vol.21 (2013 ) No 10, P.227.(In Chinese)

[3] Y. Wang and J. Yan: New Economy, Vol.35 (2016 ) No 23, P. 131-132.(In Chinese) 